\title{
CAROLINE MANIAQUE: GO WEST! DES ARCHITECTES AU PAYS DE LA CONTRE-CULTURE
}

\author{
Marseille: Éditions Parenthèses. 2014, 244 páginas, formato 24x17 cms. ISBN: 9782863642887
}

Jorge Torres Cueco

Catedrático del Departamento de Proyectos Arquitectónicos. Escuela Técnica Superior de Arquitectura. Universitat Politècnica de València.

Persona de contacto: jtorrescueco@gmail.com

G

o West es el título del monográfico de la revista Architectural Design de septiembre de 1973 dedicado al viaje de estudiantes y arquitectos norteamericanos al oeste de las Montañas Rocosas y del que este libro toma su portada. Es el relato del descubrimiento de un nuevo mundo o, mejor dicho, de una nueva forma de entenderlo y de estar en él, que vino a calificarse como "contracultura". Caroline Maniaque, en un espléndido trabajo, narra esta epopeya de parte de una generación que dejó de creer en el "american way of life" para proponer una vida comunitaria y alternativa en el seno de la naturaleza. Parte de este trabajo fue desarrollado por la autora en French Encounters with the American Counterculture 1960-1980 (London - New York: Routledge, Taylor \& Francis Group, 2011), fruto de una beca de la Fundación Graham.

Entre los años sesenta y ochenta, situados entre la crisis de la modernidad y la aparición del posmodernismo, aflora en Estados Unidos este pensamiento alternativo como respuesta a una producción indiscriminada y anodina en todos los estamentos culturales. Coincide con un momento de desconfianza en el progreso, ante la Guerra Fría y los conflictos de Corea y, sobre todo, Vietnam. Surge el movimiento hippie y comunidades estudiantiles alternativas, que proponen unas nuevas formas de acercamiento a la producción y una oposición a las formas de vida burguesa. Detrás estaba el pensamiento de Herbert Marcuse, Lewis Mumford, Iván Illich o Jacques Ellul, de tendencias anti-tecnológicas, anti-institucionales y próximas al anarquismo.

En este trabajo de amplio sentido cultural Caroline analiza las causas de este fenómeno y su repercusión en la arquitectura y en el pensamiento medioambiental. Nos propone una historia comparada entre dos sociedades que se entremezclan, se interfieren y a su vez, se distinguen. Si en Europa el neomarxismo induce, en su antagonismo contra las fuerzas dominantes, a luchar y subvertir el orden establecido; en Norteamérica se configura una cultura y sociedad escoradas al margen del sistema. Esta contraposición se nos ofrece a través de un trabajo de microhistoria. Por un lado, se nos revela a partir del viaje de arquitectos franceses que conocieron y difundieron esta contracultura mediante publicaciones como Architectural Design o L'Architecture d'Aujourd'hui. Para ello, se recurre a entrevistar a un buen número de arquitectos y artistas que han viajado "al oeste" y han conocido este movimiento en su particular epopeya a través de los Estados Unidos, en donde adquieren libros y revistas, que se convertirán en nuevos referentes a su regreso.

Por otro lado, se rastrean publicaciones como el Whole Earth Catalog (objeto de otro libro magnífico escrito por Caroline Maniaque en colaboración con Meredith Gaglio), concebido por Stewart Brand entre 1968 y 1974, como un catálogo de saberes, herramientas, educación o construcción, con una visión holística y humana frente a la especialización del mundo. También Shelter, dirigida desde 1973 por Lloyd Khan y Bob Eaton, ofrecía imágenes de otra arquitectura nada convencional. (Publicada en castellano como Cobijo por Herman Blume en 1975). Ambas tenían el aspecto de manuales de autoconstrucción - en los que se condensaba cultura material y tradición artesanal e insistía en la autosuficiencia y la autonomía de los sujetos bajo los principios de "do it yourself" y el libre acceso a herramientas y medios.

Las imágenes que nutrían estas publicaciones presentaban hábitats alternativos, antimodernos, afín a una concepción de una sociedad preindustrial donde se exaltaba el trabajo manual. Una de las imágenes más recurrentes era la de las cabañas de madera arcaicas y arquetípicas, construidas con materiales del lugar en una celebración de la vida -análogas a las imágenes de los pioneros el Far west, que elevaban en comunidad sus ballon-frame, todos a una, con la recompensa de un banquete en el seno de la naturaleza 
con los productos que de ella se han extraído y directamente elaborado. En cierto modo, se consideraba que la arquitectura formaba parte de procesos comunitarios y participativos, ajenos a la producción habitual, individual y especulativa.

Otros referentes transitaban desde las estructuras ligeras, textiles o neumáticas, como las cúpulas geodésicas de Buckminster Fuller, con sus posibilidades de transformación y reciclaje, a las edificaciones de tierra de los indios pueblo del estado de Nuevo México o las ilustraciones extraídas de la Arquitectura sin Arquitectos publicada por Bernard Rudofsky en 1964. En ambos casos, la idea de autoconstrucción autosuficiente y participativa estaba presente. Además se contemplaba la utilización de todo tipo de materiales. Desde la recuperación de elementos como puertas, ventanas, carrocerías de vehículos o fragmentos de chapa, hasta la utilización de bidones de agua -cuyo interés técnico, por sus posibilidades de conservación de la energía o el reciclaje, transcendía lo meramente formal. La arquitectura podía realizarse sin proyecto previo, en acto, como un procedimiento técnico y directo por el que se conciliaban necesidades y medios disponibles a mano.

Una incipiente preocupación ecológica acompañaba a sus promotores. Probablemente aquí nacieron las primeras nociones conscientes acerca del bioclimatismo, la sostenibilidad y la autonomía energética, tanto por el rechazo al progreso desenfrenado como por la crisis del petróleo que empezaba a acusar la dependencia de los sistemas energéticos.

Las casas-barcaza en Sausalito, las cúpulas autoconstruidas de Drop City en Colorado, la "ciudad experimental" de Arcosanti (Arizona) fundada por Paolo Soleri o las múltiples cúpulas, cabañas o estructuras inflables -como las promovidas por Ant Farm- que se construyeron a lo largo de la costa oeste, fueron algunas de las realizaciones más conocidas y lugares casi de peregrinaje de estos nuevos pioneros en su exploración de nuevos lugares y paisajes.

La transferencia a Francia de todas estas cuestiones tendrá un gran reflejo no tanto en reproducciones de Drop City o de cabañas arcaicas, como a través de diversas publicaciones que ponen su acento en un pensamiento ético y ambiental. Actue/ dedicará una buen número de sus números a mensajes político-ecológicos, La face cachée du Soleil a las reflexiones técnicas y científicas sobre la energía solar, Habitats (1977) como versión francesa de Shelter, los cuatro volúmenes de Le Catalogue des ressources (1975-83) bajo la inspiración también de Whole Earth Catalog, u otras contemporáneas como La guele ouverte o Le sauvage, por ejemplo, mantienen vivo este mensaje técnico, social y cultural en favor de las energías alternativas y sostenibles. No es una paradoja que algunos de los jóvenes protagonistas de aquel momento estén ahora en los consejos de dirección de algunas de las empresas más reconocidas en tecnología solar.

Desde finales del siglo pasado, en el contexto de una crisis mundial, muchos de estos argumentos como el bioclimatismo, el reciclaje y la sostenibilidad, la recuperación de sistemas tradicionales y ejecución manual -arquitectura de tierra, adobe, madera o bambú-, la producción a través de procesos participativos y autogestionados, la atención a las necesidades del hombre en el seno de su comunidad propia e intransferible, así como una nueva atención a la arquitectura alternativa al margen de los circuitos comerciales, forman parte de las cuestiones en las que están implicados los frentes más avanzados de la arquitectura contemporánea y que hunden sus raíces en este periodo tan fértil y generosamente estudiado por Caroline Maniaque. 